\title{
GOVERNMENT ESPOUSAL OF PRIVATE CLAIMS BEFORE INTERNATIONAL TRIBUNALS
}

\author{
MaxtmmLian KoessLeR*
}

I

I

NTERNATIONAL law has not so far developed a generally accepted theory to explain the nature of "diplomatic protection." Yet in the postwar era this phrase will be employed to an extent unknown before the war to define the action taken by state against state to secure redress of alleged wrongs done individuals or corporations. Although many of these claims will be settled by mutual agreement of the respective foreign offices, in many cases the issues will be submitted to an international body of arbitration or adjudication. Such litigation may become the most important aspect of postwar "diplomatic protection."

The term itself is not very felicitous since it does not describe an essential or characteristic feature of the institution. The unique character of this international litigation does not lie in the employment of diplomatic measures. ${ }^{2}$ Its peculiarity is based on the fact that the claim of a private person, normally without judicial standing as against a foreign state, is espoused by a state and thus converted into a government claim which will be heard by the appropriate international tribunal. An historical annalogy may be suggested. It appears that "interposition," in the sense just referred to, is similar to the representation of the serf by his lord under feudal law. ${ }^{3}$ This feudal representation grew out of the fact that the serf, devoid of a standing in the barons' courts, would have been a defenseless victim of aggression by any other lord but for the championship of his own lord. Similarly, the private person today, unrecognized by international courts or arbitration bodies, would be without legal protection against an

* Member of the New York Bar; Attorney, Civilian Personnel Division, Overseas Branch, United States Department of War.

I The same is of course true of the synonymously used terms, "diplomatic intervention" and "diplomatic intercession."

2 Dunn, The Protection of Nationals 20 (1932).

3 According to Radin, Handbook of Anglo-American Legal History 46I (r936), "a kind of representation is inherent in the whole Feudal theory. The duty of protection of the vassal involved on the lord's part championing the vassal against a powerful oppressor..... The serf [had] in no .... court . . . any standing at all. If an injury was done to a serf, it must be vindicated at the lord's instance." 
offending foreign state were not that private person's claim espoused by his government.

In the light of this analogy the gist of the institution of diplomatic protection would seem to lie in its remedial aspect rather than in the substantive character of the interest involved. It is not because the protecting state feels offended by the wrong done to one of its nationals, but in order to give the latter a workable substitute for the inaccessability of an international forum, that the strong arm of the government is extended to the private interest. This approach, as will be observed later, is essentially different from the classical one suggested by Vattel.

A streamlined law of nations, granting to private persons a standing before international courts and arbitration commissions, could do away with the roundabout relief through diplomatic protection, just as the emancipation of the serfs eliminated the need for feudal representation. However, in spite of some steps in this direction, ${ }_{4}^{4}$ it appears that the stage has not been set for such a fundamental innovation. Diplomatic protection with all its shortcomings, e.g., the dilatory effect of its rather cumbersome procedure and the possibility of its being abused in a way harmful to the peace of the world, remains a vital part of international law. Professor Borchard has described it as "a political institution which innumerable precedents from foreign office and arbitral tribunals have brought within the framework of a fairly consistent, if somewhat flexible, legal code."s These rules are, indeed, flexible. Most of them rest on what may perhaps

\footnotetext{
4 For a recent discussion of this point, with reference to exceptional cases where access to international tribunals was granted to individuals bringing claims against states, see Hudson, The Permanent Court of International Justice, x920-1942 395-99 (rev. ed. I943). Probably the first instance of access before an international tribunal being given to the interested private person, rather than to the state of which such person was a national, arose under the Rhine treaties of $183 \mathrm{I}$ and 1869 . Chamberlain, The Regime of the International Rivers: Danube and Rhine 20I, 237 (I923). More recently access was granted to individuals by the Central American Court of Justice. Ralston, International Arbitration from Athens to Locarno 240 (1929). The general aspects of the problem were discussed some years ago at a meeting of the American Society of International Law. 35 Proceedings Am. Soc. Int. L. I4 (I94I). Wright, Human Rights and the World Order I6 (I943), de lege ferentda, suggested that, "the practice of considering only states subjects of international law should be not regarded as a fundamental principle, but only as a procedural convenience which should not prevent the examination of other procedures which may under present conditions prove more convenient." Similar propositions, confusing somewhat the de lege lata with the de lege ferenda viewpoints, have been suggested in Bishop, Nationality in International Law, 37 Am. J. Int. I. 320 (r943). However, article 34 of the new Statute of the International Court of Justice provides in part: "Only states may be parties in cases before the Court." Jessup, The International Court of Justice of the United Nations: With Text of Statute, Foreign Policy Reports 154, I69 (1945). But see United States ex rel. North American Dredging Co. v. United Mexican States, Gen. Cl. Com'n, United States-Mexico, Op. of Commissioners 2r, 23-24 (1927).
}

$s$ Borchard, The Protection of Citizens Abroad and Change of Original Nationality, 43 Yale L. J. 359, 36x (1934). 
be called an international "convention," to use the term in the sense familiar to students of British constitutional law. If flexibility is one of the chief virtues of this "legal code," it would appear to be of some practical interest to demonstrate that one of those rules ${ }^{6}$ appears to be of questionable value, both in its alleged theoretical foundation and in its exclusionary consequences. Such criticism, however, is incidental to the main thrust of the present study which is principally devoted to an analysis of the legal nature of the institution under consideration. Such an analysis must develop two lines of discussion: it must define the position of the protecting state with regard to the defendant state; and it must determine the legal character of the relation between the protecting state and the private person whose claim is espoused.

II

It has been generally accepted that the moment a state has officially declared that it will "espouse" the claim or assume "diplomatic protection" of its national, the "pro foro externo" control of the claim belongs exclusively to the protecting government. This means two things: first, that in so far as the procedure'is concerned, the government is the sole and independent party-plaintiff, so that any procedural step or declaration can be made only by the government; second, that in so far as the defendant or opponent state is concerned any substantive disposition of the claim, including discharge or compromise, may be made only by the protecting state, with binding effect upon the interested private person, irrespective of his assent or protest. Many writers have endorsed this thesis. Professor Borchard has no doubt that,

As between the government and its own citizen the claim may in some degree be regarded as private. It becomes international in character when the government espouses it and presents it diplomatically to the debtor government. When it is thus taken up, the private claim becomes merged in the public demand of the government, so that from the international point of view the government, having made the claim its own, assumes the character of the party-plaintiff.?

In the same work Professor Borchard says: "Diplomatic interposition in the technical sense consists in the pressure of a claim by official representation, under the authority and in the name of the government."

\footnotetext{
6 "As a general rule, a break in the national ownership of a claim, as by assignment or change in nationality of the claimant, defeats the clair.." 5 Hackworth, Digest of International Law 802 (I943).

7 Borchard, The Diplomatic Protection of Citizens Abroad 356-57 (xgr5).

${ }^{8} \mathrm{Ibid}$. , at $44 \mathrm{r}$. On another occasion Professor Borchard stated: “.... international law and practice have developed on the theory that .... when the state espouses the claim of its
} 
Similarly, the Permanent Court of International Justice in one of its pronouncements concerning the Mavromatis Palestine Concession stated: "Once a state has taken up a case on behalf of one of its subjects before an international tribunal, in the eyes of the latter the state is the sole claimant."9 Judge Parker, in his capacity as umpire of the United StatesGermany Mixed Claims Commission, was certain that such was the correct theory:

When .... a claim is espoused, the nation's absolute right to control it is necessarily exclusive. In exercising such control it is governed not only by the interest of the particular claimant but by the larger interests of the whole people of the nation and must exercise an untrammeled discretion in determining when and how the claim will be presented and pressed, or withdrawn or compromised, and the private owner will be bound by the action taken. Even if payment is made to the espousing nation in pursuance of an award, it has complete control over the fund so paid to and held by it and may, to prevent fraud, correct a mistake, or protect the national honor, at its election return the fund to the nation paying it or otherwise dispose of it. ${ }^{\mathrm{xo}}$

It is doubtful whether occasional textual and judicial statements which loosely refer to the protecting state as the "representative" of the private person affected ${ }^{\text {II }}$ were intended as a challenge to the theory advanced by Professor Borchard, Judge Parker, and certain international tribunals.

citizen, it has become a national public claim; that the state has full control over it; that it may settle it or drop it on any terms it chooses; and that the citizen has no right to control the prosecution." Borchard, op. cit. supra, note 5 , at 363 .

9 Judgment 2 (Jurisdiction), concerning the Mavromatis Palestine Concession, Permanent Court of International Justice, Series A, No. 2, at 12 (1924); see also Hackworth, op. cit. supra, note 6 , at 489 .

ro Mixed Cl. Com'n, United States-Germany, Administrative Decision No. V I75, Igo (1924). "The United States is claimant.-Though conducted in behalf of their respective citizens, governments are the real parties to international arbitrations. .... If in the decisions, opinions, and proceedings of the Commission American nationals are referred to as claimants it will be understood that this is for the purpose of convenient designation, and that the Government of the United States is the actual claimant." Mixed Cl. Com'n, United StatesGermany, Administrative Decision No. II 8 (1923); see opinion rendered on August I4, I9I2, in re Alsop Award, by the then Solicitor for the United States Department of State, J.R. Clark, Jr., Legal Aspects Regarding the Ownership and Distribution of Awards, 7 Am. J. Int. L. 382, 383 (19I3); Hackworth, op. cit. supra, note 6 , at 488. Even such a conservative exponent of the traditional doctrine as Whiteman makes this concession: "The national continues, however, to possess certain rights in the claim. He has for example at least what might be described as an expectancy coupled with an interest that the state espousing his claim will collect it and pay him the indemnity thus collected, less expenses. .... These rights in the claim are ordinarily assignable. ...." I Whiteman, Damages in International Law 275 (I937).

Ix "Claims may be divided into two broad classes: first, those which are based upon private complaints of individuals whose government acts as their representative in espousing their cause; secondly, those which concern the State itself considered as a whole." 2 Hyde, International Law 888 (2d rev. ed. 1945); Ralston, The Law and Procedure of International Tribunals r 48 (rev. ed. I926); Eagleton, The Responsibility of States in International Law 22I (I928); cf. Z. \& F. Assets Realization Corp. v. Hull, 3rI U.S. 470, 487 (r940). 
References to the representative capacity of the protecting state were undoubtedly designed to emphasize the fact that, though the protecting state plays the role of the party-plaintiff, its action originated in and has the purpose of championing a private interest.

It is believed that "representative" in this connection should be avoided because it is not technically correct. The person appearing or acting for the prosecution of the claim may properly be called a "representative" only if he does not act in his own name but as the agent of another. If, as in the case of the protecting state, he appears and acts in his own name, he is not a representative of the party-claimant, but is himself the partyclaimant. As claimant he may belong to one of two distinct groups. $\mathrm{He}$ may be the "real party in interest"-that is to say, he may not only litigate the claim but may also be the holder of the substantive right involved." He may, on the other hand, be the "nominal plaintiff," "use plaintiff," or "plaintiff for the use of another"13 - a party-plaintiff prosecuting a right that, as a matter of substantive law, is vested in a third person. ${ }^{x 4}$ In order to determine which of these two alternatives most accurately describes the relation between the protecting state and the protected private person a critical review of Vattel's famous rationale of diplomatic protection is essential. ${ }^{\mathbf{x}}$

\section{III}

Vattel said, "Whoever ill-treats a citizen indirectly injures the State, which must protect that citizen. The sovereign of the injured citizen must

12 N.Y. Civ. Prac. Ann. (Gilbert-Bliss, I942) § 2ro.

It may be interesting to note that the French legal maxim: Nul en France ne plaide par procureur (Laborde-Lacoste, Précis elémentaire de procédure civile 4I, 42 [Paris: 1939]), which has today substantially the same meaning as the American "real party in interest" rule, originally read $\mathrm{Nul}$ en France ne plaide par procureur hormi le roi. It meant in the droit coutumier that only the lord could plead by attorney, unless a special letter of dispensation, a lettre de grace, was issued. Esmein, Cours elémentaire d'histoire du droit français 389 (r4th ed., Paris, x92I); Radin, op. cit. supra, note 3 , at 254 n. 7. For a similar rule in the old English law (appearance in court by attorney requiring a special leave from the king under his prerogative) see Maitland, The Forms of Action at Common Law 24 (I94I).

${ }^{{ }^{3} 3} 39$ American Jurisprudence, Parties § 14 (I942).

${ }^{4}$ The "plaintiff for the use of another" form represents one of those splits between substance and procedure which were commonplace in the early common law, e.g., the famous ejectment suit of the classical common law, with a fictitious party as the nominal plaintiff. This division is not entirely absent in more recent practice, e.g., the suits under the United States Materialmens' Act, referred to in Fleischmann Construction Co. v. United States ex rel. Forsberg, 270 U.S. 349, 35 I (x926).

15 Recent discussions of the classical doctrine appear in Whiteman, op. cit. supra, note Io, at 8o, 82, 275; Hostie, A Systematic Inquiry into the Principles of International Law Dealing with Diplomatic Protection, x9 Tulane L. Rev. 79 (I944); Wormser, Collection of International War Damage Claims 3 (I944); Hanna, Nationality and War Claims, 45 Col. L. Rev. 30 , 309 ( $(945)$. 
avenge the deed, and, if possible, force the aggressor to give full satisfaction or punish him, since otherwise the citizen will not obtain the chief end of civil society, which is protection." ${ }^{\prime 6}$

It was implied in this statement and has always been understood by those who followed Vattel's lead, that the right which the espousing state attempts to vindicate by the exercise of diplomatic protection is its own right rather than the right of the citizen. Recovery is sought for an injury to the protecting state rather than for an injury to the protected citizen. An unequivocal indorsement of this doctrine was made by the Permanent Court of International Justice in the Mavromatis case:

By taking up the case of one of its subjects and by resorting to diplomatic action or international judicial proceedings on his behalf, a state is in reality asserting its own rights-its rights to ensure, in the person of its subjects, respect for the rules of international law. ${ }^{77}$

This sweeping proposition was reaffirmed by the same court in the Panevezy-Saldutiskis Railway case. ${ }^{x}$ The same idea, though in a somewhat diluted form, has been suggested by Professor Wright.x The United States Department of State in a semi-official publication has apparently indorsed Vattel's doctrine. ${ }^{20}$ Current acceptance of this classical position is epitomized by the recent statement that:

The theory of international claims .... is that a nation espouses a claim of its national and makes the national's claim its own because an injury to the national or his property is regarded as an affront to the nation..$^{2 x}$

It might thus appear that international practice, particularly that of the Permanent Court of International Justice, has given full effect to Vattel's theory. The indorsement of the classical doctrine has not, how-

${ }^{26}{ }_{2}$ Vattel, Le Droit des gens c. $6, \S 7$ I (ed. of 1758 , as translated by the Carnegie Institute, rgi6). (Italics supplied.)

${ }_{77}$ Permanent Court of International Justice, supra, note 9.

${ }^{8}$ Panevezy-Saldutiskis Railway Case, Permanent Court of International Justice, Ser. A/B, No. 76, at I6 (1939); see also Case of Antoine Fabiani (France v. Venezuela), arbitrated pursuant to the protocol of February 19 , I9O2, in which the court said: "When France intervened in behalf of her national, the claims of Fabiani were no longer individual and private claims; they became national. The right to intervene exists in the indignity to France through her national. .... It is the national honor which is to be sustained." See Whiteman, op. cit. supra, note Io, at 279 .

Ig "The practice of diplomatic protection of nationals abroad has often resulted in the arbitration of claims, the actual, if not the theoretical beneficiaries of which are individuals." 2 Wright, A Study of War 909 ( $\mathrm{r}_{942)}$.

20 "In theory an unredressed injury to an alien constitutes an injury to his state, giving rise to international responsibility." Hackworth, op. cit. supra, note 6, at 47 .

${ }^{2 x}$ Hanna, op. cit. supra, note ${ }_{5}$, at 309 . 
ever, been followed by a strict application of the Vattel dogma. It is, indeed, surprising to find those international tribunals which pay tribute to Vattel assessing the amount of recovery to be allowed to a protecting state on the basis of the injury suffered by the protected private person. Is it possible to reconcile this practice with the theory that it is an injury to the state rather than to the affected private person for which the state raises its claim? The Permanent Court of International Justice has been aware of this apparent conflict between theory and practice. The Court has labored very hard to build a bridge:

It is a principle of international law that the reparation of a wrong may consist in an indemnity corresponding to the damage which the nationals of the injured state have suffered as a result of the act which is contrary to international law. This is even the most usual form of reparation. .... The reparation due by one state to another does not however change its character by reason of the fact that it takes the form of an indemnity for the calculation of which the damage suffered by a private person is taken as the measure. ... The damage suffered by an individual is never, therefore, identical in kind with that which will be suffered by a state; it can only afford a convenient scale for the calculation of the reparation due to the state..$^{22}$

The attempt to distinguish between the "kind" of damage and the "scale for the reparation" may be ingenious, but it certainly is not convincing. The Courtapparently sought refuge in dogmatic propositions when it became apparent that its practice was not in harmony with its theory. It should be a reasonable conclusion that, if damages are assessed on the basis of the injury suffered by the private person, those damages represent a reparation due to that individual.

The departure from Vattel's doctrine has not been restricted to the measure of damages. In one case an international tribunal has, by implication at least, ignored the classical principle. In I905 the Canadian authorities seized and detained an American fishing vessel, the Tattler. Before the United States government could intervene, the owner of the ship reached an agreement with the Canadian authorities. Pursuant to this settlement the vessel was released and the ship owner paid a fine and signed a written waiver of any right or claim that he might have in connection with the incident. Later he sought and obtained the protection of the United States government. The United States filed a claim for damages before the AngloAmerican Tribunal, established under the special agreement of Igro, alleging unlawful seizure and detention of the Tattler. The American position was that the waiver should not be binding on the United States because the injury was to the state and could not be compromised by a pri-

${ }^{22}$ Case of the Factory at Charzow (Claim for Indemnity, Merits), Permanent Court of International Justice, Series A, No. 17 , at 27,28 (1928). 
vate person. The Tribunal, in denying the soundness of the American position, stated:

It has been objected that the renunciation of and guarantee against any claims are not binding upon the Government of the United States, which presents the claim.

But in this case the only right the United States Government is supporting is that of its national, and consequently in presenting this claim before this Tribunal, it can rely on no legal ground other than those which would have been open to its national.23

The Tribunal, though not expressly referring to the principle upon which the Vattel dogma rests, took unequivocal exception to it. Nevertheless, little attention has been paid by writers to the inconsistency between the Vattel dogma and the result in the Tattler case. Furthermore, the Tattler case is not the only one wherein judicial authorities have departed from the Vattel position. ${ }^{24}$ Nor have the writers unanimously subscribed to the doctrine that harm inflicted upon a private person is an injury to the state. 25

It is suggested that the Vattel doctrine is a veritable spawning-ground of dangerous quarrels between nations. To consider each injury done to a national abroad as an affront to the honor of the nation easily lends itself

${ }_{23}$ The Tattler, Nielsen's Report 489, 49I (1926). For a brief summary of the case see Hackworth, op. cit. supra, note 6 , at 492 . The Tattler case usually is referred to in connection with and distinguished from theproblem involvedin the so-called Calvo clause. While the Tattler case tested the validity of a private waiver given after the event complained of, the probleminvolved in the Calvo clause is the question of the validity, as against a state, of a waiver of diplomatic protection by a national of the state in advance of any wrong committed against him. Hackworth, op. cit. supra, note 6, at 635; Harvard Research on Responsibility of States, 23 Am. J. Int. L., supp. I3I, at 202 (I929).

${ }^{24}$ Judge Parker, sitting as umpire on the United States-Germany Mixed Claims Commission, said: ".... the control of the United States over claims espoused by it before this Commission is complete. But the generally accepted theory formulated by Vattel, which makes the injury to the national an injury to the nation and internationally therefore the claim a national claim which may and should be espoused by the nation injured, must not be permitted to obscure the realities or blind us to the fact that the ultimate object of asserting the claim is to provide reparation for the private claimant." Mixed Cl. Com'n, United StatesGermany, Administrative Decision, No. V I 75, I92 (I924). The United States-Mexico Mixed Claims Commission in a unanimous opinion stated: "Ordinarily a nation will not espouse a claim on behalf of its national against another nation unless requested so to do by such national. When, on such request, a claim is espoused, the nation's absolute right to control it is necessarily exclusive. .... But the private nature of the claim inheres in it, and is not lost or destroyed so as to make it the property of the nation, although it becomes a national claim in the sense that it is subject to the absolute control of the nation espousing it." Case of William A. Parker, Gen. Cl. Com'n, United States-Mexico (Convention of 1923), Op. of Commissioners 35,36 (r927). Compare Lipstein, Conflict of Laws before International Tribunals, 29 Transactions of the Grotius Society 5I, 53-54 (r944).

25 ". . . the nation appears as a party suing not for its own benefit but for the benefit of its citizens. .... It is not for the insult to the dignity of the nation that recovery is sought .... but for the specific injury to each of the citizens represented by the claimant government." Ralston, op. cit. supra, note II, at supp. I47-48; see Hyde, op. cit. supra, note II; Hanna, op. cit. supra, note 15 , at 3 ro. 
to "abuses of the right to protection .... which are intalerable to any self-respecting nation and are prolific breeders of international friction." ${ }^{26}$ This is particularly true in view of the fact that there may be a bona fide difference of opinion, in a given situation, as to whether as a matter of international law a wrong has or has not been done to a national of the complaining nation. The controversybetween Great Britain and the Transvaal, ${ }^{27}$ the disputes between the United States and certain Latin-American countries previous to the inauguration of the "good neighbor" policy, and the German and Italian attempts to assert protection over nationals abroad, are all examples of the disastrous consequences of "diplomatic protection" gone wild. On the other hand, the distinction between the interests of the nation and private rights has been wisely drawn by the United States in the controversy over the Mexican oil expropriations. ${ }^{28}$

There may be cases in which an injury done to a citizen will assume the character of an injury done to the nation. This was obviously one of the premises upon which the decision was based in the famous controversy between the United States and Canada over the sinking of the I'm Alone. Compensation was denied the ship owner but the sum of $\$ 25,000$ was awarded to Canada because of the wrong done to that country.9 Such cases should be the exception rather than the rule. To consider the state as the vicarious sufferer of each injury inflicted upon any of its nationals would seem to be a strong overstatement and a dangerous generalization.

Conceding the substantial distinction between the domestic-law and the international-law approaches, ${ }^{30}$ it may nevertheless be pointed out that in the field of domestic law each injury inflicted upon a member of the community does not assume the character of an injury to the community itself. Domestic law wisely distinguishes between torts and crimes. Only under particular circumstances, specified by the penal law, will an

${ }^{26}$ Dredging Co. of Texas v. Mexico, Gen. Cl. Com'n, United States-Mexico (Convention of r923), Op. of Commissioners $2 x, 26$ ( $\left.x_{927}\right)$.

${ }^{27}$ The British position in that fatal Uitlander dispute was substantially that British subjects resident in Transvaal should be granted the rights of citizens. Mowat and Slosson, History of the English Speaking Peoples 467 ( $x_{943}$ ).

${ }^{28}$ The American private interests represented astronomic figures. Action by the United States government was limited, nevertheless, to the so-called extension of good offices rather than to the exercise of diplomatic protection proper. Subsequent events culminating in an amicable settlement of the affair proved the soundness of the American policy, both with regard to the maintenance of desirable relations between this country and Mexico and with regard to the satisfaction of the private interests involved. For an excellent discussion of the legal problems involved in that cause celebre, see Kunz, The Mexican Expropriations (I940).

292 Hackworth, Digest of International Law 707 (194r).

${ }^{30}$ Lauterpacht, Private Sources and Analogies of International Law 35 (1937). 
injury done to the individual so much affect the public interest that reaction by the state itself seems justified. The fact that the injured private person happens to be a national abroad should not be considered sufficient to change the private injury into a public offense.

It is suggested that the protecting state, in spite of its being the sole party-plaintiff in the prosecution of the claim, is not the "real party in interest," but is a nominal plaintiff suing for the benefit of the protected private person. The state has a derivative cause of action, somewhat similar to that of a stockholder-plaintiff in a derivative suit, ${ }^{3 x}$ who is generally said to sue "in the right of the corporation," though he is himself the party-plaintiff. ${ }^{32}$ While the right to the remedy or the Rechtsschutzanspruch $^{33}$ is exclusively vested in the espousing state, the substantive right belongs to the private person. ${ }^{34}$

The correctness of this position has nothing to do with the question whether, as a matter of domestic law ${ }^{35}$ the relationship between the protecting state and the injured private person will be considered as a trusteebeneficiary connection. This should be apparent from the fact that the

${ }^{37}$ 'The analogy of the derivative stockholder's suit has been suggested in connection with a related problem of international law. Beckett, Diplomatic Claims in Respect of Injuries to Companies, I7 Transactions of the Grotius Society I93 (1932).

${ }^{32}$ The suggested similarity is subject to certain qualifications the statement of which would require a technical discussion beyond the present purpose.

${ }^{33}$ For tentative information on this important conception see Dumbauld, Interim Measures of Protection in International Controversies I6 (1932).

34 This proposition seems to have some support: "For the protection of [the individual's] interests, as a member of a particular group, the whole machinery of diplomatic protection and international intercourse is provided. Fis rights can be protected only through his state; but, in this process, the state is his representative, and not an end in itself. .... If he has no standing before international courts, it is not because his rights are not recognized by them, but because of the greater facility and convenience with which such cases can be handled with his state to represent him." Eagleton, op.cit.supra, note Ir; "[There is] . . . confusion between the rules of procedural and substantive law, in those cases where the state appears before an international tribunal to defend rights on behalf of its subjects." Aufricht, Personality in International Law, $37 \mathrm{Am}$. Pol. Sci. Rev. 217, 243 (I943). "En la forme il semble qu'on soit resté à la doctrine de l'Ancien Régime, mais, dans la réalité cachée sous cette apparence, c'est bien pour defendre un droit individual qu'intervient l'etat demandeur." "'Looking to the form it would seem that one still conforms to the doctrine of the Ancien Regime, but in reality the claiming government intervenes in order to defend a private right.") Politis, quoted in Hofmannsthal and Berger, International Protection of Axis Victims and Revindication of Their Property Rights 28, n. 63 (1942); see Hofmannsthal, Draft of Proposed Restitution Law for Axis and Axis-occupied Countries, zo N.Y.U. L. Rev. 245, 249-50 (I945).

35 ". . . . the first stage, that is, the espousal and diplomatic presentation of the claim and determination of its validity and amount, is governed by, and must be conducted in accordance with, rules and principles of international law. It seems equally sound to say that the second stage, that is, the distribution of the award among those entitled to receive it, is a matter not of international law, but of municipal law. ...." Clark, Jr., op. cit. supra, note ro, at 382; see 3 Whiteman, Damages in International Law 2035 (1937); Wormser, op. cit. supra, note I5, at 3 . 
trust institution does not exist in most of the civil law countries, ${ }^{36}$ though those nations are members of the community of nations and, as such, are entitled to the privilege of exercising diplomatic protection. As a matter of fact British as well as American courts have been loath to acknowledge the existence of a trust between the state and the affected private person concerning the amounts recovered by the former. ${ }^{37}$

\section{IV}

Although there is no need to discuss all the technical details involved in diplomatic protection, ${ }^{38}$ it may be well to consider one special rule that is believed by many writers to reflect an acceptance of the Vattel doctrine.

It has been established as a rule of practice that no nation can

assert a claim of a private nature against another nation, unless such claim possesses the nationality of the nation asserting it continuously from its origin to the time of its presentation and even of its final adjudication by the authorized tribunal. This is but another way of saying that a change in the nationality of a claim, through itsvoluntary or involuntary transfer, deprives it of the remedy of enforcement through diplomatic protection. 39

${ }^{36}$ This refers, of course, to trusts in a strictly technical sense, and not to generalizations such as, "The trust idea is essentially simple. Under it one person owns and manages specific property for the economic benefit of another." Powell, 'Cases and Materials on the Law of Trusts 2 (r940).

37 "The notion that the Queen of this country, in receiving a sum of money in order to do justice to some of her subjects, to whom injustice would otherwise be done, becomes the agent of these subjects, seems to me really too wild a notion to require a single word of observation beyond that of emphatically condemning it. In like manner, to say that the sovereign becomes the trustee for subjects on whose behalf money has been received by the Crown appears to be equally untenable. .... The distribution of that must be left to Her Majesty's discretion; no petition of right has ever been held to be applicable in such a case." Cockburn, C. J., in Rustomjee v. Queen, [1876] × Q.B.D. 487,492 , cited with approval in Civilian War Claimants Ass'n v. King, [1932] A.C. I4, 19, 24, 27. A similar argument was made by the United States Court of Claims in one of the so-called. "Alabama Insurance" cases. Great Western Ins. Co. v. United States, I9 Ct. Cl. 206, 217 (1884); see United States v. La Abra Silver Mining Co., 32 Ct. Cl. 462, 5 I3 (I894); Clark, Jr., op. cit. supra, note Io, at 386, suggests that the fund, when received, is a national fund, in which claimants have no strict legal or equitable rights. A contrary doctrine appears in 29 Stat. 32 (I896), r3 U.S.C.A. \& II (I940), providing that "Hereafter all moneys received in by the Secretary of State from foreign governments and other sources, in trust for citizens of the United States or others, shall be deposited and covered into the Treasury"; see Borchard, Decisions of the Claims Commissions, United States and Mexico, 20 Am. J. Int. L. 536, 540 (1926); cf. Opinion of Umpire Parker, Mixed Cl. Com'n United States-Germany, Administrative Decision No. V I 75 (I924).

${ }^{38}$ The most important of these rules seems to be the requirement of the exhaustion of the so-called local remedies. Hackworth, op. cit. supra, note 6, at 47 I. Borchard states: "Claimant governments dispense with the requirement of exhausting local remedies when those remedies appear insufficient, illusory or ineffective in securing adequate redress." Borchard, op. cit. supra, note 7 , at 332 .

${ }^{39}$ Mixed Cl. Com'n, United States-Germany, Administrative Decision No. V I75 (r924). In the same decision Umpire Parker said that "... . it may well be doubted whether the alleged rule has received such universal recognition as to justify the broad statement that it is 
While this formula emphasizes the applicability of the rule to the contingency of a transfer of the claim from the national of one state to the national of another state, the requirement also applies to the break in the continuous nationality of the claim through transfer of the allegiance of the affected private person. ${ }^{40}$ The attempt has been made to explain this rule as a logical outgrowth from Vattel's theory: "If the aggrieved person is not a national at the time of the injury, there is no such affront to the nation to which he may subsequently come to owe allegiance." ${ }_{4 x}$

The comment is then deprived of any force it may have possessed by the following statement: "Moreover, if he ceases to be a national before the claim is espoused, a nation before an international tribunal has no basis for its claim." 42

The weakness of the attempt to rationalize this rule by reference to the classical doctrine is due to the fact that such a rationale will at best cover only one part of the rule, i.e., the requirement of original nationality of the claim. The requirement of continuous nationality does not follow from Vattel's dogma. If there is either a transfer of the claim or a change in the allegiance of the private person affected, the logical consequence of Vattel's doctrine should be just the opposite of the accepted rule. The Italian scholar Quadri suggested this when he said: "If the state is injured by an injury to one of its nationals, the right of the former to claim reparation should persist irrespective of a change in the nationality of the individual." 43

The theoretical foundation of the rule, in so far as it is said to rest upon the Vattel doctrine, would seem to be highly questionable. In fact, as Professor Borchard has suggested, "The general rule can only be explained on the ground that diplomatic protection is merely a supplementary or extraordinary legal remedy, which has no absolute sphere of operation and may be modified in application wherever it appears reasonable." 44

The requirement of continuous nationality did not develop as a matter of logic but apparently arose out of the fear that to hold otherwise would

an established rule of international law. .... Those decisions which have adopted it as a whole have recognized it as a mere rule of practice." Ibid., at 176, I79. Concerning the continuity requirement as such, see Hyde, op. cit. supra, note Ir, at 888; Wormser, op. cit. supra, note I5, at 32 .

$4^{\circ}$ Hackworth, op. cit. supra, note 6 .

41 Hanna, op cit. supra, note 15 , at 309 .

${ }^{2}$ Ibid.

${ }^{43}$ Author's translation of Quadri, La Sudditanza nel diritto internazionale 44-45 (1936).

44 Borchard, op. cit. supra, note 7, at 667. 
result, as Judge Parker has said, in converting strong nations into claim agencies for the nationals of smaller states. ${ }^{45}$

There is, of course, the danger that transfer of claims from the national of one state to the national of another state will result in an abuse of diplomatic protection. Notorious precedents support the concern expressed by some authorities. However, the degree of this danger should not be overestimated. It presupposes that a private person, attempting to convert a strong nation into his claim agency, will find that nation willing to play his game. Without that support the adoption of a new nationality, or the transfer of the claim to the national of another state, will not accomplish the ulterior purpose. It is a principle almost universally accepted that a citizen is not, as of right, entitled to receive the diplomatic protection of his government. ${ }^{6}{ }^{6} \mathrm{It}$ is well established that it is within the discretion of the United States government whether diplomatic protection shall be exercised in a given case. There are certain typical situations in which the Department of State as a rule refuses to intercede on behalf of an American national. ${ }^{47}$ Under international law a state has the right, under certain circumstances, to exercise diplomatic protection, but the national of a state, under most domestic laws, does not have the assurance that the state will exercise diplomatic protection in his favor. ${ }^{48}$ This is not to deny that under normal circumstances a citizen has a strong moral claim to the international support of his government. As a matter of actual practice a refusal of diplomatic protection will never take place in the absence of extraordinary circumstances. Certainty, or a high degree of probability, that a claim has been transferred or a nationality acquired for the sole pur-

${ }_{45}$ Mixed Cl. Com'n, United States-Germany, Administrative Decision No. V I75, I77 (I924). Foreign Office practice and arbitral tribunals have rejected the suggestion that an injured citizen be allowed "to choose his own protector by a shift of nationality." Borchard, op. cit. supra, note 5 , at 360 .

${ }_{46}^{6}$ Pre-Nazi Germany was an apparent exception to this rule. Article II2 of the Weimar Constitution contains a passage the English version of which reads: "All German citizens within and without the boundaries of the Reich have the right of protection by the Reich against foreign countries." McCain and Rogers, The New Constitutions of Europe I98 (I923). The provision was taken over from Article 3, Section 6 of the Imperial German Constitution, I Laband, Das Staatsrecht Des Deutschen Reiches I52 (5th ed., Tübingen, I9II).

${ }_{47}$ Seckler-Hudson, Statelessness I7 (I934); Jessup, Revising Our Nationality Laws, 28 Am. J. Int. L. I04, ro7 (I934); I Oppenheim, International Law 540 (5th ed., I937). For a discussion of the British view see China Navigation Co., Itd. v. Attorney-General, [r932] 2. K.B. 197 (concerned with the more narrow problem of the existence of a duty of the Crown to afford military protection to an English company trading in the China seas).

$4^{8}$ "One of the most important and delicate of all international relationships . . . . has to do with the protection of the just rights of a country's own nationals when these nationals are in another country." Opinion of Mr. Justice Black in Hines v. Davidowitz, 3T2 U.S. 52, 64 (I94I); cf. Slaughter-House Cases, I6 Wall. (U.S.) 36, 79 (I872). 
pose of enlisting the diplomatic protection of a given state is one of those unusual circumstances in which a nation, caring for its dignity, will not be impressed by the nominal nationality of the claim.

Although the requirement of continuous nationality might operate to exclude such claims raised in unusual circumstances, it is believed that more frequently the rule works hardships upon bona fide petitioners for diplomatic protection. The transfer of a private claim will not always be motivated by the desire to secure the protection of the second state. In many cases the transfer will be made for reasons unrelated to an attempt to make a claim-agency out of the second state. Similarly, the change of the nationality of the holder of a private claim may be induced by motives unrelated to the claim. The ancient maxim, "once a citizen, always a citizen," has given way to the principle of expatriation, successfully sponsored by the United States.49 Political and economic conditions prompt individuals to change their nationality. The policies of the totalitarian countries drove thousands of their nationals from their homes and in many cases deprived these people of their nationality, rendering them stateless. Thousands today seek a new nationality, regardless of the effect such action may have upon any claim that might be made against their former homeland. In other cases marriage with a foreigner is the inducement for the adoption of a new allegiance. It is suggested that these individuals should not be penalized by being denied diplomatic protection by their adopted country.

There may be good reason for denying them the exercise of diplomatic protection against their country of origin, even though this traditional selfrestraint would seem to be out of place in the case of the victims of practices which have been found bad enough to be labeled as crimes against humanity by the International War Crimes Commission. At the least they should enjoy the diplomatic protection of their adoptive nation as against a third country.

The case against the requirement of continuous nationality has been concisely stated by Hofmannsthal and Berger:

We cannot but point out the dangers which hover around demanding the same citizenship at two different moments, sometimes very far apart. During such a period, transfer of the rights in question may be effected to one or more citizens of other nations; this transfer may be inevitable through inheritance or seizure. Ought such an

49 The United States Expatriation Act of July 27, I868, I5 Stat. 223 (I868), 8 U.S.C.A. 801 (1942), has not been expressly abrogated by the Nationality Act of 1940, 54 Stat. II37 (I940), 8 U.S.C.A. $\$$ I-I8 (I942). On the expatriation problem in general see Flournoy, Naturalization and Expatriation, 3I Yale L.J. 702, 848 (I922); Flournoy, Expatriation, 6 Encyc. Soc. Sci. 3 (I93I). 
event do away with the possibility of recovering the damage done or enrich the responsible state? The first state could not claim because the right would be no longer vested in its subject and the second state could not so proceed as it had not yet conferred nationality on its citizen when the injury was done. This theory is a direct hindrance to the acquisition of a citizenship to which the individual feels inclined by allegiance and to which he is entitled by domicile, because it would make him lose the protection of his former state without acquiring protection of the new state. It is especially harmful in times where many cases of damage have to be considered and also injures countries which favor the view that foreigners living in them for a long time ought to become naturalized..$^{50}$

Conservative adherents to traditional doctrines may find it difficult to accept these dissident propositions. However, it is suggested that Francis Lieber's comment upon domestic law applies with equal force to international law:

A code is not a herbarium, in which we deposit law like dried plants. Let a code be the fruit grown out of the civil life of a nation, and contain the seed for future growth. ${ }^{\text {sr }}$

We are at the threshold of an era in which international law will have a (last?) chance to make a fundamental contribution to the construction of world order out of world chaos. In order that international law may vindicate itself, it must be willing to take stock of those theories or rules which, in spite of a venerable age, may have no greater justification for survival than the wig in the official garb of the British judge.

\footnotetext{
so Hofmannsthal and Berger, op. cit. supra, note 34, at 29-30; see also Hyde, op. cit. supra, note II, at 895; Whiteman, op. cit. supra, note Io, at I29; Wormser, op. cit. supra, note I5, at 39; Hanna, op. cit. supra, note 15 , at 3 ro.

${ }^{5}$ Lieber, Legal and Political Hermeneutics 33-34 (3d ed., r880).
} 